\section{Tolerance of Turf-type Tall Fescue Established from Seed to Postemergence Applications of Mesotrione and Quinclorac}

\author{
J. Scott McElroy ${ }^{1,3}$ and Greg K. Breeden ${ }^{2}$ \\ Plant Sciences Department, The University of Tennessee, 2431 Joe Johnson \\ Drive, 252 Plant Sciences Building, Knoxville, TN 37996
}

Additional index words. turfgrass establishment, herbicide injury, turfgrass tolerance, tall fescue, Schedonorus phoenix, Lolium arundinaceum

\begin{abstract}
Research was conducted to evaluate the tolerance of tall fescue to mesotrione applied during establishment from seed. Nine field studies were conducted over a 3-year period (2004-2006) near Knoxville, Tenn., to evaluate the tolerance of seedling tall fescue [Schedonorus phoenix (Scop.) Holub] to mesotrione and quinclorac. The first evaluated tall fescue tolerance to single and sequential applications of mesotrione compared with quinclorac (multiple application study). The second evaluated the timing of mesotrione application on tall fescue injury and establishment (timing study). In the multiple application study, all treatments injured tall fescue $23 \%$ or less. Quinclorac reduced tall fescue groundcover up to $17 \% 63$ days after emergence (DAE). Mesotrione at $0.28 \mathrm{~kg} \cdot \mathrm{ha}^{-1}$ applied 28 and $42 \mathrm{DAE}$ or 14, 28, and $42 \mathrm{DAE}$ decreased groundcover only $4 \%$ and $6 \% 63 \mathrm{DAE}$. In the timing study, mesotrione at $0.28 \mathrm{~kg} \cdot \mathrm{ha}^{-1}$ applied at 7 and $28 \mathrm{DAE}$ injured tall fescue $17 \%$ to $21 \% 7$ and 14 days after application; however, injury subsided to less than $10 \%$ by 28 days after application. Only mesotrione at $0.28 \mathrm{~kg} \cdot \mathrm{ha}^{-1}$ applied 7 DAE resulted in delayed tall fescue groundcover at 70 DAE. Variation was observed in Fall 2005 evaluations compared with other evaluations, which may be attributable to delayed seeding date and cool, wet conditions.
\end{abstract}

Weed management options during seeded establishment of tall fescue [Schedonorus phoenix (Scop.) Holub; Lolium arundinaceum (Schreb.) S.J. Darbyshire] are limited. Siduron is often applied at planting for preemergence control of warm-season annual grasses such as crabgrass (Digitaria spp.) species (Moshier et al., 1976; Shearman et al., 1980). Siduron does not control annual broadleaf weeds and has little postemergence activity (Vencill, 2002). Quinclorac can be used both pre- and postemergence for control of crabgrass and some broadleaf species, but it does not control goosegrass [Eleusine indica (L.) Gaertn.] (Johnson, 1996; Reicher et al., 1999; Vencill, 2002; Zawierucha and Penner, 2001)

Mesotrione is currently being evaluated for use in turfgrass. Mesotrione inhibits p-hydroxyphenylpyruvate dioxygenase (EC 1.13.11.27), a precursor to plastoquinone and tocopherols (Mitchell et al., 2001; Pallett et al., 1998; Secor, 1994). The predominant symptom of mesotrione activity is tissue

\footnotetext{
Received for publication 1 Aug. 2006. Accepted for publication 6 Oct. 2006.

We thank the East Tennessee Research and Education Center-Plant Sciences Unit farm crew for technical assistance of this research.

${ }^{1}$ Assistant Professor.

${ }^{2}$ Research and Extension Associate.

${ }^{3}$ To whom reprint requests should be addressed; e-mailmcelroy@utk.edu.
}

whitening with subsequent plant necrosis. Whitening is attributed to a decrease in carotenoid production resulting from decreased phtytoene desaturase activity. Mesotrione is an indirect inhibitor of phytoene desaturase because plastoquinone serves as a cofactor for phytoene desaturase, the first step in the carotenoid synthesis pathway converting phytoene to $\zeta$-carotene and successive carotenoids. The lack of tocopherols also contributes to plant death through a decrease in buffering capacity to reactive oxygen species (Matringe et al., 2005).

Some turfgrass species have been reported to have tolerance to mesotrione. Mesotrione applied at $0.44 \mathrm{~kg} \cdot \mathrm{ha}^{-1}$ injured Kentucky bluegrass less than $25 \% 8$ weeks after treatment and controlled crabgrass (Digitaria spp.) more than $80 \% 8$ weeks after treatment (Beam et al., 2004). Sequential applications of mesotrione at $0.14 \mathrm{~kg} \cdot \mathrm{ha}^{-1}$ applied at seeding and 4 weeks after seeding (WAS) of tall fescue controlled crabgrass species more than $90 \%$ with tall fescue cover exceeding 90\% 22 WAS (Askew et al., 2003). In comparison, tall fescue groundcover was $15 \%$ to $35 \%$ less than the nontreated at 22 WAS when treated with quinclorac applied at $0.84 \mathrm{~kg} \cdot \mathrm{ha}^{-1}$ at seeding or $0.84 \mathrm{~kg} \cdot \mathrm{ha}^{-1}$ at seeding followed by (fb) $0.42 \mathrm{~kg} \cdot \mathrm{ha}^{-1} 4 \mathrm{WAS}$ (Askew et al., 2003). Tall fescue has also been reported to be more tolerant than Kentucky bluegrass, red fescue, and perennial ryegrass to the $p$-hydroxyphe- nylpyruvate dioxygenase-inhibiting herbicide isoxaflutole (Bhowmik and Drohen, 1998).

Mesotrione provides control of large crabgrass (Digitaria sanguinalis L.) (Johnson and Young, 2002), smooth crabgrass [Digitaria ischaemum (Schreb.) Schreb ex. Muhl.], henbit (Lamium amplexicaule L.), broadleaf plantain (Plantago major L.), yellow woodsorrell (Oxalis stricta L.) (Askew et al., 2003), and nimblewill (Muhlenbergia schreberi J.F. Gmel.) (Willis et al., 2005). Based on these experiments, it was hypothesized that mesotrione could be used during seeded establishment of tall fescue with minimal reduction in grow-in speed. Experiments were conducted to evaluate seedling tall fescue tolerance and grow-in to mesotrione and quinclorac.

\section{Materials and Methods}

Research was conducted at the East Tennessee Research and Education Center-Plant Sciences Unit in Knoxville, Tenn., in 2004, 2005, and 2006. Two separate experiments were conducted to assess turf-type tall fescue tolerance to mesotrione. Expt 1. evaluated single and sequential postemergence applications of mesotrione versus quinclorac (multiple application study). Expt. 2 evaluated tall fescue establishment as effected by timing of mesotrione applications (timing study). The multiple application study was conducted as five separate trials over a 3-year period, whereas the timing study was conducted as four separate trials over a 2-year period. Seeding dates, soil types, and cultivars used are presented in Table 1 . The seeding date for Fall 2005 was delayed as a result of irrigation repairs during September. Although seeding turf-type tall fescue in October is not optimum, it is not uncommon in Tennessee.

All field preparation and cultural practices were kept consistent for all experiments. Previous vegetation was killed with two applications of glyphosate $\left(2.2 \mathrm{~kg} \cdot \mathrm{ha}^{-1}\right)$ applied 8 and 3 weeks before seeding. Soil was tilled to a $25-\mathrm{cm}$ depth and disked until the seedbed was smooth and fine. Soil was cultipacked to firm the soil, dragged with a harrow rake to remove dead vegetation, and further firmed by rolling with a smooth roller.

Both experiments were seeded with turftype tall fescue at $293 \mathrm{~kg} \cdot \mathrm{ha}^{-1}$ pure live seed. For Spring 2006 experiments, 'Kittyhawk' tall fescue was unavailable locally; therefore, 'Falcon II' was used. Starter fertilizer $(6 \mathrm{~N}-$ $10.5 \mathrm{P}-9.9 \mathrm{~K})$ was applied at a rate of $200 \mathrm{~kg} \cdot \mathrm{ha}^{-1}$. Seeds were broadcast-applied in two directions to ensure uniformity, lightly dragged with a leaf rake in two directions, rolled with a smooth roller to provide further firming, and covered with a germination blanket (A.M. Leonard, Piqua, Ohio). Trials were irrigated twice daily with $\approx 0.5 \mathrm{~cm}$ of water to maintain adequate surface moisture for germination. The germination blanket was removed at $14 \mathrm{~d}$ after seeding (DAS). In all cases, seed emerged $7( \pm 1)$ DAS. 
Table 1. Information for individual trials conducted.

\begin{tabular}{llcc}
\hline & \multicolumn{2}{c}{ Multiple application study } & \\
\hline Trial & Seeding date & Soil type $^{z}$ & Tall fescue cultivar \\
\hline Spring 2004 & 24 Mar. 2004 & Etowah silt loam & Kittyhawk \\
Fall 2004 & 6 Sept. 2004 & Etowah silt loam & Kittyhawk \\
Spring 2005 & 7 Apr. 2005 & Sequatichie loam & Kittyhawk \\
Fall 2005 & 11 Oct. 2005 & Sequatichie loam & Kittyhawk \\
Spring 2006 & 29 Mar. 2006 & Sequatichie loam & Falcon II \\
& & Timing study & Kittyhawk \\
Fall 2004 & 6 Sept. 2004 & Etowah silt loam & Kittyhawk \\
Spring 2005 & 7 Apr. 2005 & Sequatichie loam & Kittyhawk \\
Fall 2005 & 11 Oct. 2005 & Sequatichie loam & Falcon II \\
Spring 2006 & 29 Mar. 2006 & Sequatichie loam &
\end{tabular}

${ }^{z}$ Complete soil classification: Etowah silt loam soil (fine-loamy, siliceous, semiactive, thermic Typic Paleudult) and Sequatichie loam soil (fine-loamy, siliceous, semiactive, thermic Humic Hapludult).
All trials were fertilized 14 and 28 DAS at $200 \mathrm{~kg} \cdot \mathrm{ha}^{-1}$ with $24 \mathrm{~N}-2.6 \mathrm{P}-9.9 \mathrm{~K}$ fertilizer, after which no additional fertilizer was applied. Beginning 14 DAS, trials were irrigated daily at $0.7 \mathrm{~cm}$ daily for 4 weeks and then were irrigated every other day at $0.7 \mathrm{~cm}$ to supplement rainfall events.

Research plots were arranged in a randomized complete block design with four replicates. Experimental units were $2.25 \mathrm{~m}^{2}$ $(1.5 \times 1.5 \mathrm{~m})$. Herbicide applications were made with a $\mathrm{CO}_{2}$ pressurized sprayer calibrated to deliver $280 \mathrm{~L} \cdot \mathrm{ha}^{-1}$. The spray boom used four $8002 \mathrm{XR}$ flat fan nozzles (Spraying Systems Co., Wheaton, Ill.) with $25-\mathrm{cm}$ spacing. Tall fescue injury and tall fescue turf groundcover were visually rated for both experiments using a 0 to 100 scale. For tall fescue injury, $0 \%$ equals no visual injury and $100 \%$ equals complete plant death. To facilitate discussion, $20 \%$ or more injury was deemed as commercially unacceptable injury as a result of the potential detrimental effect on eventual turfgrass groundcover. For tall fescue groundcover, $0 \%$ equals no tall fescue turf present and $100 \%$ equals complete tall fescue groundcover. In the multiple application study, Spring 2004 groundcover was not rated. Weed species spectrum varied among experiments; therefore, no weed control data are presented.

For the multiple application study, herbiafter emergence (DAE). Except for the Fall responded at 1 to 2 leaf stage (14 DAE), one to two tillers (28 DAE), and three to four tillers (42 DAE). For the Fall 2005 experiment, seedling growth stage corresponded at 1 to 2 leaf stage (14 DAE), one tiller ( 28 DAE), and one to two tillers (42 DAE). There were 13 treatments in the multiple application study: mesotrione applied as a single application at 0.14 and $0.28 \mathrm{~kg} \cdot \mathrm{ha}^{-1} 14,28$, or 42 DAE; mesotrione applied as sequential applications at 0.14 or $0.28 \mathrm{~kg} \cdot \mathrm{ha}^{-1} 28 \mathrm{DAE}$ $\mathrm{fb} 42$ DAE; mesotrione applied as sequential applications at 0.14 or $0.28 \mathrm{~kg} \cdot \mathrm{ha}^{-1} 14 \mathrm{DAE}$ fb 28 DAE fb 42 DAE; quinclorac applied as a single application at $1.68 \mathrm{~kg} \cdot \mathrm{ha}^{-1} 14 \mathrm{DAE}$; quinclorac applied as a sequential application at $0.84 \mathrm{~kg} \cdot \mathrm{ha}^{-1} 14 \mathrm{DAE}$ and $28 \mathrm{DAE}$; and mesotrione at $0.28 \mathrm{~kg} \cdot \mathrm{ha}^{-1}$ plus quinclorac at cide treatments were made at 14, 28, and $42 \mathrm{~d}$ 2005 experiment, seedling growth stage cor-
$1.68 \mathrm{~kg} \cdot \mathrm{ha}^{-1}$ applied 28 DAE. All mesotrione treatments contained $0.25 \% \mathrm{v} / \mathrm{v}$ nonionic surfactant (X-77 Spreader; Loveland Industries, Greeley, Colo.) while quinclorac treatments included $0.6 \% \mathrm{v} / \mathrm{v}$ methylated seed oil (MSO Concentrate; Loveland Industries) according to herbicide label recommendations (Anonymous, 2004). The combination treatment contained $0.6 \% \mathrm{v} / \mathrm{v}$ methylated seed oil. At the initiation of these trials in 2004, mesotrione at $0.14 \mathrm{~kg} \cdot \mathrm{ha}^{-1}$ was assumed to be the one-time application rate for potential turfgrass use. Inclusion of the $2 \times$ rate of quinclorac at $1.68 \mathrm{~kg} \cdot \mathrm{ha}^{-1}$ was included as a comparison with mesotrione at $0.28 \mathrm{~kg} \cdot \mathrm{ha}^{-1}$.

For the timing study, herbicide treatments were made at seeding, 7,14 , or 28 DAE. Two mesotrione rates, 0.14 and $0.28 \mathrm{~kg} \cdot \mathrm{ha}^{-1}$, were evaluated at each application timing. At seeding, applications were made after seeding and the final rolling occurred but before the germination blanket was placed. All mesotrione treatments contained $0.25 \% \mathrm{v} / \mathrm{v}$ nonionic surfactant.

Data were subjected to analysis of variance $(P=0.05)$. Injury ratings for nontreated plots were not included in the analysis as a result of decreased potential heterogeneity of separate trials were analyzed as separate environments and the treatment-by-environthe treatment effect was tested (McIntosh, 1983). Means were separated using Fisher's protected least significant difference. For the timing study, data were analyzed as a two (herbicide rate) by four (application timing) factorial arrangement, was used as the error component. A pairwise contrast was conducted to evaluate the effect of mesotrione rate, whereas orthogonal contrasts were conducted to evaluate the effect of herbicide timing (Steele et al., 1997). Fisher's protected least significant difference is presented as a means of making all possible comparisons and comparison with the nontreated, but these are not meant to supercede preplanned contrasts.

\section{Results and Discussion}

Multiple application study. No differences in tall fescue injury were observed between experiments; therefore, data were pooled over experiments. No mesotrione alone treatment injured tall fescue more than $25 \%$ regardless of rate or timing (Table 2 ). Mesotrione applied $14 \mathrm{DAE}$ at $0.28 \mathrm{~kg} \cdot \mathrm{ha}^{-1}$ injured tall fescue greater than $0.14 \mathrm{~kg} \cdot \mathrm{ha}^{-1}$ when evaluated 21 DAE. No rate difference was observed between single applications applied 28 or 42 DAE. With respect to single applications, only mesotrione applied at $0.28 \mathrm{~kg} \cdot \mathrm{ha}^{-1} 14 \mathrm{DAE}$ injured tall fescue $10 \%$ or more $7 \mathrm{~d}$ after application (DAA). Some sequential applications increased injury greater than a single application; however, no mesotrione alone treatment exceeded $23 \%$ injury. Findings of seedling tolerance to mesotrione applied sequentially is beneficial because sequential applications have been variance. For the multiple application study, ment interaction was used as the error by which in which the rate by timing within year effect

Table 2. Turf-type tall fescue turfgrass injury response to mesotrione and quinclorac treatments.

\begin{tabular}{|c|c|c|c|c|c|c|c|c|}
\hline \multirow[b]{2}{*}{ Herbicide $^{z}$} & \multirow[b]{2}{*}{$\begin{array}{c}\text { Rate } \\
\mathrm{kg} \cdot \mathrm{ha}^{-1}\end{array}$} & \multirow[b]{2}{*}{$\begin{array}{l}\text { Timing } \\
\text { DAE }\end{array}$} & \multicolumn{6}{|c|}{ Injury $^{y}$} \\
\hline & & & $\begin{array}{c}21 \mathrm{DAE} \\
(\%)\end{array}$ & $\begin{array}{l}28 \text { DAE } \\
(\%)\end{array}$ & $\begin{array}{c}35 \text { DAE } \\
(\%)\end{array}$ & $\begin{array}{c}42 \mathrm{DAE} \\
(\%)\end{array}$ & $\begin{array}{c}49 \text { DAE } \\
(\%)\end{array}$ & $\begin{array}{c}56 \mathrm{DAE} \\
(\%)\end{array}$ \\
\hline Mesotrione & 0.14 & 14 & 7 & 5 & 5 & 0 & 0 & 0 \\
\hline Mesotrione & 0.14 & 28 & & & 5 & 8 & 0 & 0 \\
\hline Mesotrione & 0.14 & 42 & & & & & 4 & 0 \\
\hline Mesotrione & 0.28 & 14 & 10 & 3 & 5 & 0 & 0 & 0 \\
\hline Mesotrione & 0.28 & 28 & & & 5 & 9 & 3 & 0 \\
\hline Mesotrione & 0.28 & 42 & & & & & 5 & 0 \\
\hline Mesotrione & 0.14 & 28,42 & & & 3 & 2 & 1 & 0 \\
\hline Mesotrione & 0.28 & 28,42 & & & 7 & 9 & 10 & 8 \\
\hline Mesotrione & 0.14 & $14,28,42$ & 8 & 6 & 8 & 3 & 9 & 2 \\
\hline Mesotrione & 0.28 & $14,28,42$ & 11 & 9 & 23 & 12 & 18 & 1 \\
\hline Quinclorac & 1.68 & 14 & 16 & 20 & 23 & 21 & 12 & 14 \\
\hline Quinclorac & 0.84 & 14,28 & 13 & 22 & 19 & 16 & 12 & 15 \\
\hline $\begin{array}{l}\text { Mesotrione plus } \\
\text { quinclorac }\end{array}$ & $\begin{array}{l}0.28 \text { plus } \\
1.68\end{array}$ & 28 & & & 10 & 13 & 11 & 11 \\
\hline $\begin{array}{l}\text { Least significant } \\
\text { difference }\end{array}$ & & & 2 & 2 & 3 & 4 & 4 & 3 \\
\hline
\end{tabular}

${ }^{\mathrm{z}}$ All mesotrione treatments contained $0.25 \% \mathrm{v} / \mathrm{v}$ nonionic surfactant, whereas quinclorac treatments included $0.6 \% \mathrm{v} / \mathrm{v}$ methylated seed oil. The combination treatment contained $0.6 \% \mathrm{v} / \mathrm{v}$ methylated seed oil.

${ }^{\mathrm{y}}$ Rating scale was $0 \%$ equals no visual injury and $100 \%$ equals complete plant death.

DAE, days after emergence. 
observed to be more effective than single applications in controlling problem weeds such as nimblewill (Willis et al., 2005). Throughout our experiments, injury to tall fescue from mesotrione was observed as minor bleached white tissue with no necrosis occurring.

Injury from quinclorac treatments persisted longer than a single application of mesotrione (Table 2). Quinclorac at $1.68 \mathrm{~kg} \cdot \mathrm{ha}^{-1}$ applied $14 \mathrm{DAE}$ injured tall fescue $20 \%$ or more for up to 28 DAA (42 DAE), whereas injury symptoms from mesotrione single applications did not persist longer than $21 \mathrm{~d}$, at which time they were $5 \%$ or less. A sequential application of quinclorac at $0.84 \mathrm{~kg} \cdot \mathrm{ha}^{-1}$ applied 14 and 28 DAE resulted in less injury to tall fescue 35 and 42 DAE than a single application at 1.68 $\mathrm{kg} \cdot \mathrm{ha}^{-1}$ applied 14 DAE. Although these injury symptoms were observed, quinclorac at $1.68 \mathrm{~kg} \cdot \mathrm{ha}^{-1}$ is twice the recommended label rate and it is not recommended that quinclorac be applied with a surfactant until 28 DAE (Anonymous, 2004). Woznica et al. (2003) reported limited reduction in green foxtail [Setaria viridis (L.) P. Beauv.] growth when quinclorac was applied without surfactant. The inclusion of an adjuvant, primarily methylated seed oil, is necessary for proper absorption of the herbicide (Enloe et al., 1999; Woznica et al., 2003; Zawierucha and Penner, 2001). Quinclorac injury observed in our research was epinasty and vertical growth cessation. Quinclorac did not induce any chlorotic or necrotic symptoms.

An experiment by treatment effect was observed for tall fescue groundcover at all rating dates (Table 3). By sorting the data by experiment, analysis revealed differences in Fall 2005 data from other location data; therefore, Fall 2005 data were analyzed separately and all other locations were pooled. An overall decrease in groundcover was observed in Fall 2005, primarily attributed to the delayed seeding date.

Excluding Fall 2005 data, although injury symptoms differences were observed between mesotrione and quinclorac treatments, no differences were observed in groundcover 28 DAE (Table 3). At 42 DAE, however, all quinclorac-containing treatments decreased groundcover to less than the nontreated, primarily attributable to lingering injury symptoms. Reicher et al. (1999) reported no groundcover reduction to Kentucky bluegrass (Poa pratensis L.) when quinclorac at $0.84 \mathrm{~kg} \cdot \mathrm{ha}^{-1}$ was applied at seeding to 84 DAE. Repeat applications and quinclorac rates above $0.84 \mathrm{~kg} \cdot \mathrm{ha}^{-1}$, however, were not evaluated by Reicher et al. (1999). Similar comparisons to tall fescue were not available. Decreased groundcover from quinclorac-containing treatments was also observed at $63 \mathrm{DAE}$ with single and sequential applications of quinclorac alone yielding $80 \%$ and $78 \%$ groundcover, respectively. Mesotrione plus quinclorac yielded similar groundcover to quinclorac-alone treatments. With respect to mesotrione-alone single and sequential applications, only mesotrione at $0.28 \mathrm{~kg} \cdot \mathrm{ha}^{-1}$ applied 28 and 42 DAE or 14,28 , and 42 DAE decreased groundcover to less than the nontreated 63 DAE. For Fall 2005, quinclorac did not decrease groundcover at 63 DAE compared with the nontreated. Although all mesotrione

Table 3. Turf-type tall fescue groundcoverage response to mesotrione and quinclorac treatments. ${ }^{2}$

\begin{tabular}{|c|c|c|c|c|c|c|c|c|}
\hline \multirow[b]{3}{*}{$\begin{array}{l}\text { Herbicide } \\
\text { treatment }\end{array}$} & \multirow[b]{3}{*}{$\begin{array}{l}\text { Rate } \\
\mathrm{kg} \cdot \mathrm{ha}^{-1}\end{array}$} & \multirow[b]{3}{*}{$\begin{array}{c}\text { Timing } \\
\text { DAE }\end{array}$} & \multicolumn{6}{|c|}{ Groundcover } \\
\hline & & & \multicolumn{3}{|c|}{ Excluding Fall 2005} & \multicolumn{3}{|c|}{ Fall 2005 only } \\
\hline & & & $\begin{array}{c}28 \mathrm{DAE} \\
(\%)\end{array}$ & $\begin{array}{c}42 \text { DAE } \\
(\%)\end{array}$ & $\begin{array}{c}63 \mathrm{DAE} \\
(\%)\end{array}$ & $\begin{array}{c}28 \mathrm{DAE} \\
(\%)\end{array}$ & $\begin{array}{c}42 \mathrm{DAE} \\
(\%)\end{array}$ & $\begin{array}{c}63 \text { DAE } \\
(\%)\end{array}$ \\
\hline Mesotrione & 0.14 & 14 & 61 & 69 & 95 & 41 & 63 & 63 \\
\hline Mesotrione & 0.14 & 28 & & 69 & 95 & & 60 & 60 \\
\hline Mesotrione & 0.14 & 42 & & & 94 & & 63 & 63 \\
\hline Mesotrione & 0.28 & 14 & 61 & 63 & 93 & 35 & 61 & 53 \\
\hline Mesotrione & 0.28 & 28 & & 69 & 95 & & 63 & 53 \\
\hline Mesotrione & 0.28 & 42 & & & 95 & & 60 & 60 \\
\hline Mesotrione & 0.14 & 28,42 & & 71 & 95 & & 63 & 63 \\
\hline Mesotrione & 0.28 & 28,42 & & 71 & 90 & & 58 & 58 \\
\hline Mesotrione & 0.14 & $14,28,42$ & 64 & 71 & 94 & 44 & 61 & 61 \\
\hline Mesotrione & 0.28 & $14,28,42$ & 61 & 63 & 84 & 36 & 53 & 53 \\
\hline Quinclorac & 1.68 & 14 & 61 & 64 & 80 & 41 & 64 & 64 \\
\hline Quinclorac & 0.84 & 14,28 & 61 & 66 & 78 & 39 & 59 & 59 \\
\hline $\begin{array}{l}\text { Mesotrione plus } \\
\text { quinclorac }\end{array}$ & $\begin{array}{c}0.28 \text { plus } \\
1.68\end{array}$ & 28 & & 68 & 81 & & 60 & 60 \\
\hline Nontreated & & & 63 & 73 & 95 & & 60 & 60 \\
\hline $\begin{array}{l}\text { Least significant } \\
\text { difference }\end{array}$ & & & 2 & 4 & 4 & NS & NS & 9 \\
\hline
\end{tabular}

${ }^{\mathrm{z}}$ All mesotrione treatments contained $0.25 \% \mathrm{v} / \mathrm{v}$ nonionic surfactant, whereas quinclorac treatments included $0.6 \% \mathrm{v} / \mathrm{v}$ methylated seed oil. The combination treatment contained $0.6 \% \mathrm{v} / \mathrm{v}$ methylated seed oil. All statistical tests were conducted at a significance level of $P=0.05$.

DAE, days after emergence.

Table 4. The effect of mesotrione timing and rate on turf-type tall fescue injury and turfgrass groundcover.

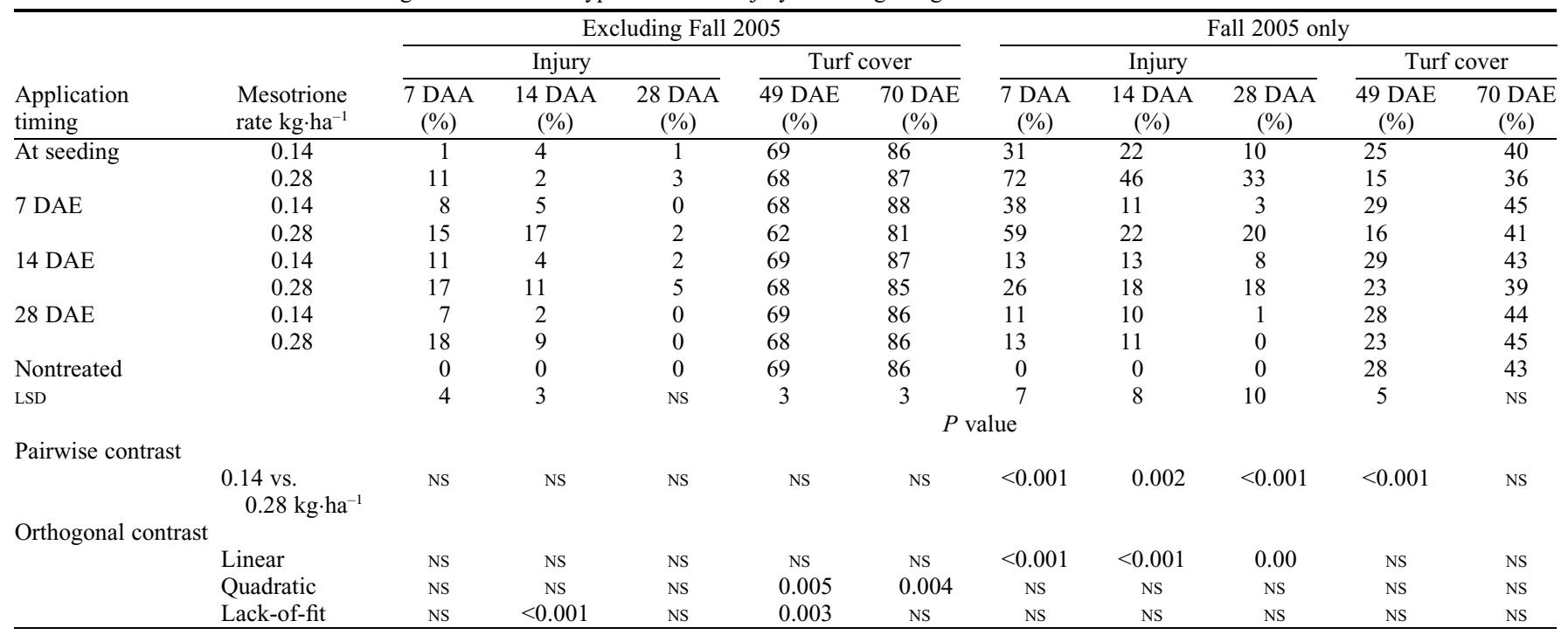

${ }^{\mathrm{z}}$ All statistical tests were conducted at a significance level of $P=0.05$. Abbreviations: DAA, days after application; DAE, days after emergence; LSD, least significant difference.

${ }^{y}$ All mesotrione treatments contained $0.25 \% \mathrm{v} / \mathrm{v}$ nonionic surfactant.

${ }^{\mathrm{N} N}$ Nonsignificant. 
at $0.28 \mathrm{~kg} \cdot \mathrm{ha}^{-1}$ treatments did not decrease groundcover statistically compared with the nontreated, these treatments did decrease groundcover to less than $60 \%$ at $63 \mathrm{DAE}$.

Comparisons to other research evaluating mesotrione applied at turfgrass seeding are limited. Pre- and postemergence applications of mesotrione were reported to not decrease the eventual grow-in of 'Crossfire II' tall fescue, whereas turfgrass coverage was reduced $15 \%$ to $35 \%$ with siduron $(6.7$ $\left.\mathrm{kg} \cdot \mathrm{ha}^{-1}\right)$ applied preemergence or quinclorac $\left(0.84 \mathrm{~kg} \cdot \mathrm{ha}^{-1}\right)$ applied pre- and postemergence (Askew et al., 2003).

Timing study. Fall 2005 data were analyzed separately as a result of a location-bytreatment effect. When data were analyzed after removing Fall 2005 data, the location by treatment was nonsignificant; therefore, all other data were pooled over location. Excluding Fall 2005 data, no difference was observed between mesotrione at 0.14 and $0.28 \mathrm{~kg} \cdot \mathrm{ha}^{-1}$ when pooled over application date (Table 4). Mesotrione at $0.28 \mathrm{~kg} \cdot \mathrm{ha}^{-1}$ applied at 7,14 , or 28 DAE injured tall fescue $9 \%$ to $18 \% 7$ and 14 DAA; however, injury decreased to less than $5 \%$ by 28 DAA. Tall fescue injury for all other treatments was less than these three treatments at 7 and 14 DAA. Although the highest injury was observed at $0.28 \mathrm{~kg} \cdot \mathrm{ha}^{-1}$ applied at 7 or 28 DAE, such injury translated into delayed tall fescue groundcover for only the 7 DAE application.

Greater overall injury and groundcover reduction was observed in Fall 2005 than other trial dates (Table 4). In addition, although the Fall 2005 multiple application study and timing study were initiated at the same time, greater injury was observed in the timing study. It was noted that although both studies in Fall 2005 were conducted on the same soil type, the timing study experienced more saturated soil conditions. In Fall 2005, mesotrione at $0.28 \mathrm{~kg} \cdot \mathrm{ha}^{-1}$ injured tall fescue greater than $0.14 \mathrm{~kg} \cdot \mathrm{ha}^{-1}$. In general, tall fescue injury decreased and turfgrass cover at 49 DAE increased as the stand age increased from at seeding to 28 DAE. Observations from Fall 2005, although an aberration, reveal the potential detrimental effect of mesotrione when applied during nonoptimal establishment conditions.

These data indicate that mesotrione can be safely used for weed management during seeded establishment of turf-type tall fescue from seed with limited negative effects on turf stand grow-in. Cool, wet environmental conditions could potentially increase mesotrione injury to tall fescue. Three sequential mesotrione applications at $0.28 \mathrm{~kg} \cdot \mathrm{ha}^{-1}$ was the most detrimental to tall fescue stand development, potentially delaying harvestability of tall fescue sod. Although quinclorac can be applied safely 28 DAE according to label recommendations, mesotrione could potentially be used earlier.

\section{Literature Cited}

Anonymous. 2004. Drive 75DF Herbicide. BASF Corp., Agricultural Products, Research Triangle Park, N.C.

Askew, S.D., J.B. Beam, and W.L. Barker. 2003. New herbicide options for seeding cool-season turfgrass in spring. Proc. South. Weed Sci. Soc. 56:85.

Beam, J.B., W.L. Barker, and S.D. Askew. 2004. Postemergence crabgrass control in Kentucky bluegrass. Proc. South. Weed Sci. Soc. 57:104.

Bhowmik, P.C. and J.A. Drohen. 1998. Postemergence selectivity and safety of isoxaflutole to cool-season turfgrass species. Proc. Northeast. Weed Sci. Soc. 52:18.

Enloe, S.F., S.J. Nissen, and P. Westra. 1999. Absorption, fate, and soil activity of quinclorac in field bindweed (Convolvulus arvensis) in fallow. Weed Sci. 47:136-142.

Johnson, B.C. and B.G. Young. 2002. Influence of temperature and relative humidity on the foliar activity of mesotrione. Weed Sci. 50:157-161.

Johnson, B.J. 1996. Tank-mixed postemergence herbicides for large crabgrass (Digitaria sanguinalis) and goosegrass (Eleusine indica) control in bermudagrass (Cynodon dactylon) turf. Weed Technol. 10:716-721.
Matringe, M., A. Sailland, B. Pelissier, A. Rolland, and O. Zink. 2005. $p$-Hydroxyphenyl pyruvate dioxygenase inhibitor-resistant plants. Pest Manag. Sci. 61:269-276.

McIntosh, M.S. 1983. Analysis of combined experiments. Agron. J. 75:153-154.

Mitchell, G., D.W. Bartlett, T.E.M. Fraser, T.R. Hawkes, D.C. Holt, J.K. Townson, and R.A. Wichert. 2001. Mesotrione: A new selective herbicide for use in maize. Pest Manag. Sci. 57:120-128.

Moshier, L., A.J. Turgeon, and D. Penner. 1976. Effect of glyphosate and siduron on turfgrass establishment. Weed Sci. 24:445-448.

Pallett, K.E., J.P. Little, M. Sheekey, and P. Veerasekaran. 1998. The mode of action of isoxaflutole. I. Physiological effects, metabolism, and selectivity. Pest. Biochem. Physiol. 62:113-124.

Reicher, Z.J., D.V. Weisenberger, and C.S. Throssell. 1999. Turf safety and effectiveness of dithiopyr and quinclorac for large crabgrass (Digitaria sanguinalis) control in springseeded turf. Weed Technol. 13:253-256.

Secor, J. 1994. Inhibition of barnyardgrass 4-hydroxyphenylpyruvate dioxygenase by sulcotrione. Plant Physiol. 106:1429-1433.

Shearman, R.C., E.J. Kinbacher, and K.A. Reierson. 1980. Siduron effects on tall fescue (Festuca arundinacea) emergence, growth, and high temperature injury. Weed Sci. 28:194 196.

Steele, R.G.D., J.H. Torrie, and D.A. Dickey. 1997. Principles and procedures of statistics: A biometrical approach. 3rd ed.WCB McGraw-Hill. New York, N.Y. pp. 157-167, 352-399.

Vencill, W.K. 2002. Herbicide handbook. 8th ed. Weed Sci. Soc. Am., Lawrence, Kans. pp. 395-396.

Willis, J.B., S.D. Askew, and J.S. McElroy. 2005 Selective nimblewill (Muhlenbergia schreberi) control in cool-season turfgrass. Weed Sci. Soc. Am. Abstr. no. 102 [CD-ROM computer file]. Weed Sci. Soc. Amer., Lawrence, Kans. (Feb. 2005)

Woznica, Z., J.D. Nalewaja, C.G. Messersmith, and P. Milkowski. 2003. Quinclorac efficacy as affected by adjuvants and spray carrier water. Weed Technol. 17:582-588.

Zawierucha, J.E. and D. Penner. 2001. Adjuvant efficacy with quinclorac in canola (Brassica napus) and turfgrass. Weed Technol. 15:220-223. 